\title{
EFL Learners' Perspectives Towards Online Reading Module of IELTS: A Study at Tertiary Level
}

\author{
Tanzina Halim \\ Faculty of Languages and Translation, King Khalid University, Abha, Saudi Arabia \\ Sayyed Rashid Ali Shah \\ College of Education and Arts, Lusail University, Lusail, Qatar
}

\begin{abstract}
This paper seeks to investigate the attitude of students towards attending IELTS (Reading) classes online. The International English Language Testing System (IELTS) is a world-wide recognized test that students/ candidates have to take to assess their English language proficiency to study or work in an Englishspeaking context. They have to either take the IELTS Academic or the IELTS General Training modules. In recent times with the shift from face-to-face to online classes, the students face many challenges while attending online classes of IELTS, especially the reading module. This study aims to find out the problems which are faced by Saudi students while attending online classes. For this, 40 undergraduate students, both males and females of a public university in Saudi Arabia, were chosen as participants to carry out the study. A survey questionnaire was administered to the students who experienced challenges in online classes of IELTS. Based on the findings, the study concludes with some recommendations about how students can overcome the challenges they face while having online classes of the Reading module of IELTS.
\end{abstract}

Index Terms — attitude, challenges, IELTS, online classes, reading module, students

\section{INTRODUCTION}

In recent years to pursue higher studies, find suitable jobs, or survive in an English- speaking environment, taking the International English Language Testing System (IELTS) is compulsory. It is stated that IELTS has become a "benchmark for language proficiency" (Templer, 2004, p.191). Since it has gained popularity over the years, IELTS stands out to be unique among other tests in terms of its claims to assess English as an international language and indicate a recognition of the expanding status of English (Uysal, 2009). As a result, the test takers of IELTS have significantly increased over the years.

IELTS has two test modules: IELTS Academic and IELTS General Training. Both these modules consist of the four modules: Listening, Speaking, Reading, and Writing. The IELTS Academic is preferred by students who want to pursue higher studies and the IELTS General Training is preferred by candidates who wish to seek jobs or migrate to an English-speaking country. However, students/ candidates find both versions of the IELTS to be highly challenging. All the modules in both versions are time-bound. Students/ candidates have to take intensive training to meet the requirements set by different educational institutions or job sectors. It is known that both versions of the IELTS tests are scored in the same way assessing the four language skills (listening, reading, writing, and speaking). For both the Academic IELTS and the General Training IELTS modules, in the reading module, test takers have to read three passages consisting of 1500- 2500 words. Test takers should answer 38-42 questions in 60 minutes. It is to be mentioned that there are three sections in the Reading module and the level of difficulty increases throughout the paper (IELTS Handbook, 2007).

Students are given a text to read in a regular face-to-face class for the reading module. They read the text on paper. They are given a couple of minutes to read the title and predict what the text could be about. The next step for the students is to go through the questions and get familiar with the type of questions. Once they are familiar with the passage and the type of questions, they start to answer them.

It is said that IELTS is a 'high stakes' exam that often takes place at the end of an intensive course, and students have to be under severe pressure to succeed (Issitt, 2008). Due to the sudden shift from face-to-face to online classes, training and being trained online for IELTS modules have become challenging for both students and teachers. Both teachers and students, cannot deny the benefits of having online classes; however, for a test like IELTS, training the students online and being trained online requires a lot of time, skills, and patience. Based on both teachers' and students' experiences regarding face-to-face classes, it is seen that in a face-to-face class, students feel more comfortable interacting with teachers. Also, it is easier to engage students more in a face-to-face class than online. Below are some advantages of having face-to-face classes of the reading module and some disadvantages of having the classes of reading module online observed by the researchers. 
Positive sides of conducting the reading module face-to-face:

1. Attendance of the students is satisfactory.

2. Participation of students in the class is satisfactory as well.

3. Most students are highly motivated to learn about the course.

4. It is mandatory for all students to bring their textbooks.

5. Handouts and materials are provided to them from time to time, keeping them engaged in class.

6. Students are engaged more in the assigned tasks.

7. Students can interact more with the teacher.

8. Students are engaged in group discussions about the text, which helps them better understand the text.

Negative sides of conducting the reading module online:

With a shift from face-to-face classes to online classes, the whole scenario has changed. With the beginning of online sessions,

1. Attendance of the students is significantly less.

2. Participation of the students has decreased, and some students just login for the sake of logging in.

3. Only a few students are interested to know about the text material.

4. It becomes difficult to monitor if all students really have the textbook with them and follow the given handouts and materials as there is no way to monitor these things.

5. There is also a lack of motivation on the students' side.

6. Students feel less motivated to interact with the teacher.

7. There are barely any discussions with classmates.

8. Students read the texts individually.

Rationale of the study: With the shift from face-to-face classes to online classes, the researchers were interested in studying the learners' perspectives regarding online classes of the reading module of IELTS because there were difficulties and challenges that both the teachers and learners faced.

While conducting the IELTS sessions in a regular face-to-face class, students would first get the Reading passage on paper. They would get a couple of minutes to read the title and predict what the text could be about. The next step would be to ask them to go through the questions and get familiar with the type of questions. Once they are familiar with the passage and the type of questions, they can answer the questions. However, some of these things were difficult to monitor online. First of all, teachers are unsure if all the students have the text in front of them. Second, whether all the students read the text cannot be ensured. While responding to the teacher's questions, only a couple of students would respond. In this case, teachers do not have access to monitor all the students and ask them to participate.

\section{Objectives of the Study}

The objectives of the present study are to find out the challenges which learners face while having the IELTS reading module class online. Therefore, the researchers have observed and monitored the performance of students critically for one semester. Based on the needs and requirements of the students, this paper aims to come up with some solutions to overcome the problems of having reading classes online.

Research Questions

This study aims to fill the gap in the literature by answering the following questions:

1. What difficulties do students face while taking the reading module of IELTS online?

2. Does reading the texts online affect their level of understanding?

3. What strategies do students follow to cope up with the problems of reading the texts online?

4. How can the challenges be overcome?

\section{LITERATURE REVIEW}

Over the years, there are many studies conducted on the reading module of IELTS. They have discussed issues like problems that candidates face while taking the reading module, how high-scoring candidates and low-scoring candidates manage to complete the test and various strategies that test-takers use to complete the test. To take the IELTS reading module, candidates must be skilled readers to complete the task. To complete the reading module successfully, test-takers have to focus, pay attention and concentrate intensely. According to Alderson (2000), "IELTS's strength is in using multiple methods of text understanding of any passage, as in real life readers typically respond to reading texts in many ways." (p. 206).

According to Grabe (2009), Grabe and Stroller (2011) and Hudson (2007), reading is an interactive process that involves the interaction between the reader and the text. According to this view of reading, Singhal (2011) points out that a skilled reader interacts with the text to understand the text thoroughly regarding both the main ideas and relevant supporting information. A skilled reader also uses several reading strategies and prior knowledge to construct meaning. For test-takers of IELTS, regarding the reading module, the strategies are no exception. In a study conducted by Ahmadian et al. (2016), reading is considered an essential skill for academic learning. It is also crucial for EFL learners because reading comprehension is integral to International English Language Testing System (IELTS). They have also pointed out that candidates used a wide variety of strategies to complete the reading task. A similar view is expressed by Chalmers and Walkinshaw (2014). Their study also discussed that participants responded to time pressure, unfamiliar 
vocabulary, and demands on working memory by employing a range of expeditious reading strategies that focused less on textual comprehension than quickly locating correct answers. Not only this, they used multiple interdependent reading strategies rather than a single independent strategy.

Ahmadian et al. (2016) also stated that candidates came up with many coping strategies. For example, guessing, highlighting and underlining key ideas, skipping, predicting, using linguistic clues to work out the meaning of words, re-reading, using non-textual clues. This research also points out predicting/ guessing to skip unnecessary information adapted by high-scoring readers. Similarly, the guessing technique is mentioned in the study of Chalmers and Walkinshaw (2014) that lower-scoring students guessed under pressure when other reading strategies failed. A similar view is shared by Feng and Chen (2016). Their work also discusses the importance of direct demonstration by teachers to help students understand reading comprehension strategies. They will use the method of thinking aloud and show students how to apply a reading comprehension strategy. As a result, students will observe the process of reading comprehension visually. Later, they will also receive feedback from teachers. In this study, the most crucial aspect in a reading class is explanation and demonstration by teachers. They will explain and demonstrate "flexible use of several kinds of reading comprehension strategies, including different applications in different contexts." (p.1179)

However, Kovalenko (2018) discusses that candidates not having the background knowledge of the texts are considered a great advantage and provide a solid justification to show that IELTS is unbiased. This view is contradictory to the view expressed by Ali et al. (2020). They state that a lack of background knowledge and familiarity with the exam topics affected the test-taker's ability to comprehend reading texts.

All these studies pointed out the fact that to be skilled readers, students have to follow some strategies to cope up with the challenges they face while taking the reading module of IELTS. Along with this, candidates have to be aware of time-management. The teacher's demonstration is also an essential factor in making the test-takers familiar with the type of questions in the reading module.

However, none of these studies show the challenges teachers and students face while having an IELTS reading module class online as teaching IELTS online seems to be a recent phenomenon. In a face-to-face class, teachers can easily guide and monitor the students throughout the reading sessions. Students can read the text, pause to think about the text, interact with the teacher and classmates to comprehend the text more thoroughly. However, in online classes, this is not possible. They have to concentrate solely on the screen, scroll up and down to locate the information. Reading on-screen makes it difficult to highlight, circle, underline key ideas and phrases. They also fail to take down notes while reading the text on the screen. Most students are not familiar with taking notes to return to the located information in the text. For a test like the IELTS, being trained online requires a lot of time, skill, and patience for students. The present study focuses on the reading module of IELTS and the difficulties students face while taking classes online.

\section{Methodology}

\section{A. Participants}

For this study both male and female students of B.A. program in English (Level-7 and 8) at a public university in Saudi Arabia were chosen. Forty students participated in this study. Their age ranged from 18- 25. Their L1 was Arabic. They have been studying the course Preparation for International Tests for one semester.

\section{B. Instruments}

The research participants were administered a survey questionnaire consisting of 16 closed items. All ordinal variables in the questionnaire were prepared on a 5-point Likert Scale starting from strongly disagree to strongly agree. The questionnaire was based on the experiences of students who had taken classes of IELTS reading module online for one semester.

\section{Data Collection Procedure}

The questionnaire was constructed on Google forms. Its link was forwarded to students through Course Messages, emails, and SMS on mobiles. Within 10 days, the data was collected. The students responded enthusiastically because they faced many challenges during this semester $\left(2^{\text {nd }}\right.$ semester Spring 2021) in the IELTS reading module.

\section{Hypothesis}

The current research validates the negative impacts of online classes and the difficulties that both students and teachers have faced in web-based teaching and learning. Based on the students' observations, the researchers have formulated this hypothesis- IELTS reading module online classes carry several negative impacts with its positive sides. If these negative impacts are not resolved, the whole learning process gets affected and learning becomes doubtful. In other words, it can be said that students do not perform well and do not get internal and external reinforcement to attend classes online. Hence, the aims of the whole pedagogy are lost and there are many challenges to achieve its goals.

\section{E. Limitations of the Study}


The study was conducted at only one university in Saudi Arabia; hence, the participants were not numerous. Also, all the students who were taking the course of IELTS online did not participate in the study.

\section{F. Ethical Consideration}

The names of the participants in the study have been kept anonymous. The participants were assured that the confidentiality of the respondent would be maintained. This questionnaire would be used only for data collection and analysis. There will be no pressure if the questionnaire is unfilled.

\section{G. Data Analysis and Interpretation}

After gathering the data, it was analysed statistically using SPSS (Version 26.0). A tabulation of descriptive statistics: minimum, maximum, mean and standard deviation was prepared to determine the students' views regarding the IELTS reading module classes online, as illustrated in table 1.

\section{FINDINGS AND DISCUSSION}

TABLE 1

LEARNERS' PERSPECTIVES TOWARDS THE ONLINE READING MODULE OF IELTS

\begin{tabular}{|c|c|c|c|c|c|}
\hline & $\mathrm{N}$ & Minimum & Maximum & Mean & Std. Deviation \\
\hline $\begin{array}{l}\text { 1. I feel that face-to-face instructions } \\
\text { from teachers are more helpful than } \\
\text { instructions online for the reading } \\
\text { component. }\end{array}$ & 40 & 1 & 5 & 4.25 & 1.171 \\
\hline $\begin{array}{l}\text { 2. I find reading the texts on the } \\
\text { screen to be more time-consuming. }\end{array}$ & 40 & 1 & 5 & 4.07 & 1.141 \\
\hline $\begin{array}{l}\text { 3. I think that reading the texts on } \\
\text { screen affects my concentration level. }\end{array}$ & 40 & 1 & 5 & 4.05 & 1.260 \\
\hline $\begin{array}{l}\text { 4. I think reading the texts on paper } \\
\text { keeps me more on track and focused. }\end{array}$ & 40 & 1 & 5 & 4.32 & 1.071 \\
\hline $\begin{array}{l}\text { 5. I apply some reading strategies for } \\
\text { locating information when I read } \\
\text { texts on screen. }\end{array}$ & 40 & 2 & 5 & 3.55 & 1.061 \\
\hline $\begin{array}{l}\text { 6. I believe that engaging in pair/ } \\
\text { group discussion in a classroom } \\
\text { environment helps me to be more } \\
\text { engaged. }\end{array}$ & 40 & 1 & 5 & 4.10 & 1.128 \\
\hline $\begin{array}{l}\text { 7. I feel hesitant to ask teachers for } \\
\text { explanations and clarification while } \\
\text { reading the texts online. }\end{array}$ & 40 & 2 & 5 & 4.00 & 1.132 \\
\hline $\begin{array}{l}\text { 8. I have to take notes while reading } \\
\text { online for a better understanding. }\end{array}$ & 40 & 1 & 5 & 4.10 & 1.081 \\
\hline $\begin{array}{l}\text { 9. I read aloud when the texts become } \\
\text { challenging to comprehend. }\end{array}$ & 40 & 1 & 5 & 4.12 & 1.202 \\
\hline $\begin{array}{l}\text { 10. I read slowly and carefully to } \\
\text { understand what I am reading. }\end{array}$ & 40 & 2 & 5 & 4.20 & .911 \\
\hline $\begin{array}{l}\text { 11. I have to adjust my reading speed } \\
\text { while reading online. }\end{array}$ & 40 & 2 & 5 & 3.85 & 1.001 \\
\hline $\begin{array}{l}\text { 12. Sometimes, I print out a hard } \\
\text { copy of the text and use it to locate } \\
\text { information. }\end{array}$ & 40 & 1 & 5 & 3.65 & 1.252 \\
\hline $\begin{array}{l}\text { 13. I feel more nervous when I read a } \\
\text { text online. }\end{array}$ & 40 & 1 & 5 & 3.05 & 1.535 \\
\hline $\begin{array}{l}\text { 14. When I read a text online, I need } \\
\text { to concentrate and focus more. }\end{array}$ & 40 & 1 & 5 & 3.88 & 1.362 \\
\hline $\begin{array}{l}\text { 15. I stop every now and then and } \\
\text { reflect upon what I am reading. }\end{array}$ & 40 & 2 & 5 & 3.88 & .939 \\
\hline $\begin{array}{l}\text { 16. I believe it requires a particular } \\
\text { skill to be a good online reader. }\end{array}$ & 40 & 1 & 5 & 3.70 & 1.159 \\
\hline
\end{tabular}

Out of 16 variables, 9 of them supported that online reading needs some special attention and focus. The participants supported this idea strongly as they scored 4 or more than 4 points on a 5-point Likert Scale. These are as follows 1. $(M=4.25$, S.D. $=1.71), 2 .(M=4.07$, S.D. $=1.141), 3 .(M=4.05$, S.D.= 1.260) 4. $(M=4.32$, S.D. $=1.071), 6 .(M=4.10$, S.D.= 1.128), $7(M=4.00$, S.D.= 1.132) 8. $(M=4.10$, S.D.= 1.202), 9. $(M=4.12$, S.D.= 1.202), 10. $(M=4.20$, S.D. .911$)$. The rest 7 variables scored less than 4 . Their mean and standard deviation were recorded and shown in the following way as 5. $(\mathrm{M}=3.55$, S.D.= 1.061) 11. $(\mathrm{M}=3.85$, S.D.= 1.001), 12. $(\mathrm{M}=3.65$, S.D.= 1.252), 13. $(\mathrm{M}=3.05$, S.D.= 1.535), 14. $(M=3.88$, S.D.= 1.362), 15. $(M=3.88$, S.D.= .939) 16. $(M=3.70$, S.D.= 1.159). Except item no. 13, the rest 6 items scored more than 3.50, so, it indicates the participants agree with these variables too. It is to be mentioned that no variables had less than 3 points which means participants agreed totally with all the responses. 
The data revealed that the respondents were not much satisfied with the online reading sessions for IELTS because they found it difficult to concentrate on applying all the reading strategies. They also had less involvement in pair/group work because of the online classes; therefore, their dissatisfaction was evident.

The findings of this study show that students face more challenges and difficulties in the online IELTS reading module than the traditional classes. They find problems with getting instructions online, whereas face-to-face instructions are more helpful and effective for them. This view is similar to the view expressed in the study of Feng and Chen (2016). Their work also discussed the importance of direct demonstration by teachers to help students understand reading comprehension strategies. They preferred to use the method of thinking aloud and show students how to apply a reading comprehension strategy. For some learners getting the instructions visually helped them to be more focused. Many learners supported the view that they had to take down notes to understand the text better. This is similar to the views expressed in the study of Ahmadian et al. (2016). There, candidates came up with many coping strategies: guessing, highlighting and underlining key ideas, skipping, predicting, using linguistic clues to work out the meaning of words, re-reading, using non-textual clues. Some learners also felt that reading text online affected their concentration level and they had to be more focused. Moreover, they had to apply some strategies for locating information while reading the texts online. The researchers here agree with Singhal (2011), who points out that a skilled reader interacts with the text to thoroughly understand the text regarding both the main ideas and relevant supporting information.

They thought engaging in pair/ group discussion would have helped them be more involved in the activities. The study also shows some students feel hesitant to ask for an explanation when they face any problem. They also have to take notes for a better understanding of the online texts. They have to read slowly and carefully and also adjust their reading speed. Some learners pointed out they feel nervous while reading a text online and they have to stop and reflect upon what they are reading. Not to mention that learners sometimes need particular skills to be good online readers, which is similar to the view expressed in the study of (Singhal, 2011). He points out that a skilled reader also uses several reading strategies and prior knowledge to construct meaning.

Based on the above discussion, it can be mentioned that online reading sessions of the IELTS reading module are challenging for most students. To be more focused, using various reading strategies and being aware of time limitations are issues that students must be aware of from the beginning of the online sessions. They must be self-regulated and take proper guidance from their instructors to overcome the obstacles they face during the online sessions.

\section{RECOMMENDATIONS}

Learners, to a certain extent, face challenges while taking IELTS Reading classes online. Based on this observation, some recommendations are given below.

- Teachers need to train the learners to be more skilled in taking reading classes online.

- $\quad$ Learners need to be self-motivated to attend online classes of IELTS.

- Learners should have more self-practice to get familiar with the online texts of IELTS.

- Teachers need to train learners more to use various reading strategies to complete the reading tasks.

- Learners should learn to be more focused during the online sessions.

- Learners should participate more in online discussions.

- There should be more interaction with teachers instead of being passive learners.

- $\quad$ Learners should be encouraged more to get involved in pair work.

- As the reading module is extremely time-bound, learners should be aware of the time limitation regarding IELTS reading module.

\section{CONCLUSION}

For many students taking online classes can be very beneficial as it saves time and they can take the classes whenever and wherever convenient. In the current context of education, the benefits of online classes cannot be denied. Both teachers and students support the view that online classes have made everything very easily accessible. However, it has to be mentioned that online classes can be advantageous for a short period. It cannot be applicable in a course like IELTS, where learners need to be trained rigorously and within time constraints. The reading module of IELTS is no doubt extremely challenging and to have high scores, learners find it difficult to cope with the challenges which come with being instructed online. Online classes can never be the solution for life-long learning. Even when technology is governing all the fields of education, there will still be some learners who would prefer to be guided by teachers and instructors face-to-face. They will still want to sit in a proper classroom to feel the classroom environment with friends and classmates to chat and share information. All these in turn, will keep learners motivated and adequately guided. The crux of the study is that online classes can never be the solution for life-long learning.

\section{ACKNOWLEDGEMENTS}

The authors extend their appreciation to the Deanship of Scientific Research at King Khalid University for funding this work through a research program under grant number R.G.P. 1/146/42. 


\section{REFERENCES}

[1] Ahmadian, M., Poulaki, S. \& Farahani, E. (2016). Reading strategies used by high scoring and low scoring IELTS candidates: A think-aloud study. Theory and Practice in Language Studies, 6(2), 408-4016. https://doi.org/10.15701tpls.0602.25

[2] Alderson, J.C. (2000). Assessing reading. Cambridge, UK: Cambridge University Press. https://doi.org/101017/cbo9780511732935

[3] Ali, H. I. H., Al Washahi, Q. \& Alhassan, A. (2020). Unpacking the challenges and accommodation strategies of Omani English-Major students on IELTS academic reading tests. Journal of Language and Linguistic Studies, 16(3), 1621-1636. https://doi.org/10.17263/jlls803922

[4] Chalmers, J. \& Walkinshaw, I. (2014). Reading strategies in IELTS tests: Prevalence and impact on outcomes. English Australia Journal, 30 (1)24-39.

[5] Feng, Q., \& Chen, L. (2016). A study on teaching methods of reading comprehensions strategies by comparison between TEM4 reading comprehension and IELTS academic reading comprehension. Journal of Language Teaching and Research, 7(6), 1174-1180. https://doi.org/175507/jltr.0706.15

[6] Grabe, W. \& Stoller, F. L. (2011). Teaching and researching reading (2nd ed.). Harlow: Longman.

[7] Hudson, T. (2007). Teaching second language reading. Oxford: Oxford University Press.

[8] IELTS Handbook. (2007). Prepare for IELTS skills and strategies: Book two; Reading and writing. The University of Cambridge, ESOL Examinations: Cambridge University Press

[9] Issit, S. (2008). Improving scores on the IELTS speaking test. ELT Journal, 62(2), 131-138. https://doi.org/10.1093/elt/cc1055

[10] Kovalenko, M. (2018). The validation process in the IELTS reading component: Reading requirements for preparing international students. Journal of Language and Education,4(1), 63-78. https://doi.org/10.17323/2411-7390-2018-4-163-78

[11] Singhal, M. (2011). Teaching reading to adult second language learners: Theoretical foundations, pedagogical applications, and current issues (2nd ed.). US: The Reading Matrix Inc.

[12] Templer, B. (2004). High-stakes testing at high fees: Notes and queries on the international English proficiency assessment market. Journal of Critical Educational Policy Studies, 2(1), 189-226.

[13] Uysal, H.H. (2009). A critical review of the IELTS writing test. ELT Journal, 64(3), 114-33

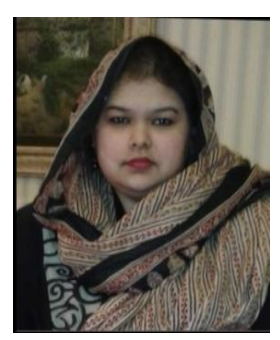

Tanzina Halim is working as a Lecturer at the Dept. of English, Faculty of Languages \& Translation, King Khalid University, Abha, Saudi Arabia. She has an M.A. in English Literature \& Language. She is TEFL certified, has Diploma in TESOL and Diploma in Teacher Training. She is interested in language teaching and creative writing and has publications in some International Journals.

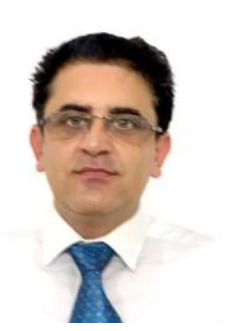

Sayyed Rashid Ali Shah works as an assistant professor of Applied Linguistics and TESOL at College of Education and Arts, Lusail University, Lusail Qatar. He has earned an MA in TESOL from Sheffield Hallam University, UK and a doctorate in TESOL from the University of Exeter, UK. Dr. Shah's research interests are teacher education, educational leadership and management, teacher leadership, assessment in ELT, and curriculum development. 